\title{
Pengaruh Ukuran Perusahaan, DER, ROA, dan Pajak Penghasilan terhadap Praktik Income Smoothing
}

\author{
Putu Rian Mahendra ${ }^{1}$ \\ Fakultas Ekonomi dan Bisnis \\ Universitas Udayana, Indonesia
}

\author{
I Ketut Jati ${ }^{2}$ \\ Fakultas Ekonomi dan Bisnis \\ Universitas Udayana, Indonesia
}

\begin{abstract}
Surel : rianmahendraa@gmail.com
ABSTRAK

Income smoothing merupakan salah satu cara pihak manajemen perusahaan dalam memanipulasi laporan keuangan perusahaan. Penelitian ini menggunakan data panel dari perusahaan sektor manufaktur yang terdaftar di Bursa Efek Indonesia periode tahun 2013-2017 untuk menganalisis pengaruh antara ukuran perusahaan, debt to equity ratio, return on asset dan pajak penghasilan, terhadap income smoothing. Hasil dari penelitian ini adalah ukuran perusahaan berpengaruh negatif signifkan terhadap income smoothing, debt to equity ratio tidak berpengaruh signifikan terhadap income smoothing, return on asset dan pajak penghasilan berpengaruh positif signifikan terhadap income smoothing.
\end{abstract}

Kata Kunci: Income Smoothing; Ukuran Perusahaan; Debt To Equity Ratio; Return On Asset; Pajak Penghasilan.

\section{Effect of Company Size, DER, ROA, and Income Tax on Income Smoothing Practices}

\section{ABSTRACT}

Income smoothing is one of the ways the company management manipulates earnings information. This research uses panel data from manufacturing companies listed in Indonesian Stock Exchange (BEI) in the period from 2013 to 2017 to analyze the effect between cash holding, firm size, growth, dividend payout ratio, and leverage to income smoothing. This results of this study are that companies size has a significant negative effect, debt to equity ratio doesn't have a significant effect to income smoothing, return on asset and income tax have a positive and significant effect to income smoothing.

Keywords: Income Smoothing; Company Size; Debt To Equity Ratio; Return On Asset; Income.

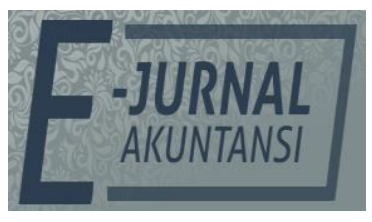

e-ISSN 2302-8556

Vol. 30 No. 8

Denpasar, Agustus 2020 Hal. 1941-1956

DOI:

10.24843/EJA.2020.v30.i08.p04

PENGUTIPAN:

Mahendra, P. R. \& Jati, I K.

(2020). Pengaruh Ukuran Perusahaan, DER, ROA, dan Pajak Penghasilan terhadap Praktik Income Smoothing. EJurnal Akuntansi, 30(8), 19411956

RIWAYAT ARTIKEL: Artikel Masuk: 19 Agustus 2019 Artikel Diterima: 22 Agustus 2020

Artikel dapat diakses : https://ojs.unud.ac.id/index.php/Akuntansi/index 


\section{PENDAHULUAN}

Suatu perusahaan terdiri dari dua pihak, yaitu pihak internal (agent) dan pihak eksternal (principal). Pihak internal perusahaan adalah orang-orang yang berada di dalam kegiatan operasi perusahaan, seperti manajemen. Pihak internal memiliki tanggung jawab terhadap kondisi keuangan perusahaan, sedangkan pihak eksternal (principal) merupakan pemilik perusahaan dan mempercayakan tanggung jawab kepada pihak internal (agent) untuk melakukan operasi perusahaan (Kholmi, 2010). Contoh dari principal adalah stakeholder dan investor yang menanamkan modalnya di perusahaan tersebut.

Sarana bagi pihak investor dalam menginvestasikan kelebihan dananya adalah pasar modal (Kristijanto \& Rachmawati, 2009). Pasar modal di Indonesia adalah Bursa Efek Indonesia (BEI). Selain sebagai wadah investasi, Bursa Efek Indonesia juga menyediakan informasi mengenai data-data dari perusahaan yang terdaftar. Para investor dapat melihat secara langsung informasi keadaan perusahaan di Bursa Efek Indonesia, sehingga dapat menjadi acuan para investor untuk melakukan kegiatan investasinya. Salah satu informasi penting dari perusahaan bagi para investor di Bursa Efek Indonesia adalah laporan keuangan. Laporan keuangan merupakan salah satu informasi yang sangat penting dalam menilai perkembangan perusahaan (Maith, 2013).

Laporan keuangan suatu perusahaan akan dilaporkan secara periodik. Jangka waktu pelaporan laporan keuangan adalah setiap bulan, setiap triwulan, ataupun setiap tahun. Dalam sebuah laporan keuangan, informasi yang paling menarik perhatian pihak investor adalah informasi laba. Informasi laba akan sangat menggambarkan keadaan atau kondisi suatu perusahaan, seperti tingkatan keuntungan perusahaan ataupun tingkat fluktuasi dari keuntungan perusahaan dari periode sebelumnya. Laba yang tinggi diperoleh perusahaan diindikasikan sebagai kinerja yang baik, sedangkan laba yang rendah diindikasikan perusahaan memiliki kinerja yang kurang baik bahkan dapat dikatakan buruk (Jariah, 2016).

Informasi laba perusahaan termuat dalam laporan laba rugi perusahaan. Laporan laba rugi terus menjadi alat informasi penting tentang perusahaan dan menunjukkan keberhasilan operasi perusahaan tersebut (Atik, 2009). Informasi mengenai tingkatan laba perusahaan dalam suatu laporan keuangan bertujuan untuk menaksir risiko investasi atau meminjamkan dana, membantu mengestimasi kemampuan laba, dan menilai kinerja manajemen (Marpaung \& Latrini, 2014). Hal ini menunjukkan betapa pentingnya informasi laba bagi pihak manajemen perusahaan.

Dalam menilai laporan laba rugi suatu perusahaan, pihak investor ataupun stakeholder ternyata tidak hanya terfokus pada jumlah laba, namun juga pada tingkatan naik turunnya laba pada periode-periode sebelumnya atau yang disebut fluktuasi laba. Laba yang tinggi namun memiliki fluktuasi laba yang tinggi akan terlihat lebih berisiko jika dibandingkan dengan laba yang tidak terlalu tinggi namun memiliki fluktuasi yang rendah. Hal ini dikarenakan fluktuasi laba yang rendah akan menunjukkan bahwa perusahaan dalam kondisi stabil dan berisiko rendah, sehingga akan menjadi magnet bagi pihak investor dalam melakukan penanaman modalnya. 
Manajer perusahaan dapat melakukan manajemen laba agar fluktuasi laba perusahaan cenderung rendah. Menurut cmanajemen laba merupakan pengaruh bentuk manipulasi yang mempengaruhi objektivitas dalam angka laba perusahaan. Dalam teori akuntansi positif, disebutkan terdapat tiga hipotesis yang mendorong manajemen perusahaan untuk melakukan manajemen laba, yaitu hipotesis rencana bonus, hipotesis perjanjian utang, dan hipotesis biaya politik.

Salah satu cara yang dapat dilakukan manajemen dalam memanajemen laba adalah melalui praktik perataan laba (income smoothing). Income smoothing adalah suatu cara pengukuran selama periode tertentu yang mengarah pada tingkat yang diharapkan atas laba yang dilaporkan (Lestari, 2017). Praktik income smoothing tidak akan terjadi apabila laba yang diperoleh perusahaan telah sesuai dengan yang diharapkan (Sumarna, 2017).

Setiap individu dapat bereaksi terhadap perubahan ambang batas dengan berbagai cara (Deuchert \& Eugster, 2019). Apabila laba perusahaan tidak sesuai dengan yang diharapkan, pihak manajemen yang menjadi pihak internal perusahaan dapat mengetahui lebih dulu informasi tersebut. Hal ini dimanfaatkan pihak manajemen untuk melakukan income smoothing baik secara real maupun secara artificial (Koh, 2003).

Konsep income smoothing dapat menghasilkan informasi laba yang tidak memadai dan dapat dianggap menyajikan informasi yang menyesatkan. Salah satu dampak dari praktik income smoothing, terutama untuk para investor adalah dapat menyebabkan kesalahan yang material terhadap penilaian investor terhadap kondisi financial perusahaan, sehingga akan menyebabkan kesalahan dalam pengambilan keputusan berinvestasi.

Praktik income smoothing juga erat kaitannya dengan tanggungan pajak perusahaan. Income smoothing dapat memperkecil jumlah laba perusahaan, sehingga perusahaan akan membayar pajak yang lebih rendah pula sehingga perusahaan cenderung terlihat lari dari pajak. Oleh karena itu, diperlukan analis sebagai peran perantara informasi penting di pasar modal (Sun, 2009).

Ukuran perusahaan merupakan perbandingan besar kecilnya perusahaan dilihat dari total aset yang dimiliki pada suatu periode tertentu (Kharisma \& Agustina, 2015). Ukuran perusahaan akan bergantung dari total aset yang dimiliki oleh perusahaan. Penelitian Kharisma \& Agustina (2015) menunjukkan bahwa ukuran perusahaan berpengaruh signifikan terhadap praktik income smoothing. Hasil yang berbeda diperoleh oleh penelitian yang dilakukan oleh Prasetya, (2013) yang menemukan bahwa ukuran perusahaan tidak memiliki pengaruh terhadap praktik (income smoothing).

Debt to equity ratio juga diduga berpengaruh terhadap praktik income smoothing. Debt to equity ratio merupakan rasio perbandingan antara utang perusahaan dengan ekuitas perusahaan. Apabila perusahaan memiliki nilai debt to equity ratio yang tinggi atau cenderung meningkat, maka risiko keuangan yang dihadapi perusahaan cenderung akan semakin tinggi pula. Penelitian Manuari \& Yasa, (2014) menemukan bahwa debt to equity ratio tidak memiliki pengaruh terhadap praktik income smoothing. Hasil yang berbeda didapat oleh Ayu \& Damayanti, (2015) yang menemukan bahwa debt to equity ratio memiliki pengaruh terhadap income smoothing. 
Return on asset merupakan salah satu rasio profitabilitas di perusahaan. Rasio ini akan menggambarkan kemampuan perusahaan menghasilkan laba dengan aset yang dimilikinya. Oleh karena itu, manajemen akan berusaha untuk membuat rasio return on asset di perusahaannya agar selalu terlihat bagus. Manajemen perusahaan akan melakukan income smoothing apabila rasio return on asset tidak sesuai dengan yang diharapkan.

Pajak penghasilan merupakan pajak yang wajib dibayar oleh perusahaan ke pemerintah dalam setiap periode. Semakin tinggi laba perusahaan, maka semakin tinggi pula pajak yang harus dibayarkan. Setiap perusahaan umumnya cenderung berkeinginan untuk membayar pajak yang seminimal mungkin. Hal ini dapat mendorong manajemen perusahaan untuk menyajikan laba yang lebih rendah dari sesungguhnya sehingga dapat memicu terjadinya praktik income smoothing namun penelitian Pratiwi \& Handayani (2014) menunjukkan bahwa pajak tidak memiliki pengaruh yang signifikan terhadap praktik income smoothing.

Perusahaan sektor manufaktur merupakan sektor perusahaan terbesar yang terdaftar di Bursa Efek Indonesia hingga saat ini. Sebanyak 144 perusahaan atau sekitar 24 persen perusahaan di Bursa Efek Indonesia bekerja di sektor manuraktur. Pada periode 2011-2015, rata-rata 50 persen perusahaan manufaktur melakukan praktik income smoothing (Sumarna, 2017).

Kasus income smoothing pernah terjadi pada perusahaan farmasi PT Kimia Farma Tbk (PT KAEF). Menurut Adhikara (2011) kasus ini terjadi karena pihak direksi telah melakukan pencatatan ganda atas penjualan pada unit Pedagang Besar Farmasi dan membuat dua daftar harga persediaan (master prices) yang berbeda yaitu pada tanggal 1 Februairi 2002 dan 3 Februari 2002. Master prices per 3 Februari 2002 merupakan master prices yang telah disesuaikan nilainya (penggelembungan) dan dijadikan dasar sebagai penentuan nilai persediaan pada unit distribusi PT KAEF per 31 Desember 2001. Hal ini menyebabkan overstated pada unit industri bahan baku, logistik sentral, dan Pedagang Besar Farmasi dan berdampak pada kesalahan penyajian laba bersih perusahaan sebesar 32,6 miliar. Hal ini merupakan suatu bentuk pelanggaran terhadap ketentuan Pasar Modal (UUPM dan peraturan Bapepam) dan juga pelanggaran terhadap Pedoman Standar Akuntan Publik (Armein, 2005).

Ukuran perusahaan merupakan perbandingan besar kecilnya perusahaan dilihat dari total aset yang dimiliki pada suatu periode tertentu (Kharisma \& Agustina, 2015). Menurut teori sinyal, ukuran perusahaan akan memberikan informasi mengenai besar kecilnya perusahaan tersebut kepada pihak eksternal. Besar kecilnya ukuran perusahaan dapat dilihat dengan menghitung logaritma natural (Ln) dari total aktiva yang dimiliki perusahaan, sehingga dapat disimpulkan bahwa semakin besar total aktiva perusahaan, maka semakin besar pula ukuran perusahaan tersebut (Prasetya, 2013).

Perusahaan yang berukuran besar umumnya lebih menyita perhatian pihak eksternal daripada perusahaan yang berukuran kecil. Ukuran perusahaan yang semakin besar akan menyita perhatian publik maupun pihak investor terkait kinerja perusahaan, sehingga akan mempersempit peluang manajemen untuk melakukan praktik income smoothing. Hal ini dapat dilihat dari beberapa perusahaan yang berukuran besar, seperti PT Indofood Sukses Makmur Tbk dan 
PT Unilever Indonesia Tbk yang memiliki Indeks Eckel $<1$ sehingga terbukti tidak melakukan praktik income smoothing. Hasil yang sama juga didapatkan dari penelitian Akbar Kharisma \& Linda Agustina, (2015) yang menemukan bahwa ukuran perusahaan berpengaruh negatif terhadap praktik income smoothing. Berdasarkan uraian, maka hipotesis yang diajukan.

$\mathrm{H}_{1}$ : Ukuran perusahaan berpengaruh negatif terhadap praktik income smoothing.

Debt to equty ratio merupakan perbandingan antar utang perusahaan dengan ekuitas perusahaan. Menurut teori akuntansi positif di hipotesis kontrak utang, perusahaan yang memiliki rasio debt to equity ratio yang tinggi akan cenderung menggunakan metode akuntansi yang akan meningkatkan pendapatan maupun laba sehingga akan menurunkan rasio utang terhadap modalnya. Ini dikarenakan peningkatan debt to equity ratio akan memberikan sinyal negatif kepada pihak eksternal karena mengindikasikan peningkatan utang perusahaan yang tidak diimbangi dengan peningkatan ekuitas, sehingga perusahaan akan memiliki risiko keuangan tinggi.

Perusahaan yang memiliki utang tinggi akan menanggung beban tetap berupa bunga dari utang yang semakin tinggi pula sehingga akan berdampak pada penurunan laba dari perusahaan tersebut dan akan mendorong manajemen untuk melakukan praktik income smoothing (Damayanti dan Suryani, 2015). Hal ini dapat dilihat dari kasus dari PT ADES yang melakukan praktik income smoothing dan mengalami peningkatan debt to equity ratio. Berdasarkan uraian, maka hipotesis yang diajukan.

$\mathrm{H}_{2}$ : Debt to equity ratio berpengaruh positif terhadap praktik income smoothing.

Return on asset adalah rasio dari laba perusahaan dengan aset perusahaan. Return on asset merupakan rasio profitabilitas bagi perusahaan. Dengan mengetahui return on asset, dapat dinilai tingkat efisiensi perusahaan dalam penggunaan aktivanya dalam operasi untuk menghasilkan laba (Josep et al., 2016). Menurut teori akuntansi positif, manajer perusahaan akan berupaya untuk mendapatkan bonus yang maksimal, sehingga akan cenderung mengendalikan angka laba dan tingkat kestabilan profitabilitas perusahaan yang menjadi syarat utama untuk para manajer dalam memperoleh kompensasi. Return on asset dapat menggambarkan seberapa efektif perusahaan menggunakan asetnya untuk menghasilkan laba (Idawati \& Wahyudi, 2015). Return on asset yang stabil akan menunjukkan bahwa perusahaan memiliki profitabilitas yang stabil dan akan memberikan keyakinan kepada investor bahwa perusahaan tersebut memiliki kinerja yang baik dalam menghasilkan laba, karena investor lebih menyukai tingkat profitabilitas yang stabil di setiap tahunnya (Amanza \& Rahardjo, 2012). Perusahaan yang profitabilitasnnya kurang baik, dapat kemungkinan menggunakan praktik income smoothing untuk menunjukkan kestabilan atau peningkatan pendapatannya (Rydqvist et al., 2014). Salah satu contoh adalah pada perusahaan PT ADES yang melakukan income smoothing dan mengalami penurunan profitabilitas. Menurut penelitian Pratiwi \& Handayani (2014), juga didapat profitabilitas berpengaruh negatif terhadap praktik income smoothing di perusahaan. Berdasarkan uraian, maka hipotesis yang diajukan.

$\mathrm{H}_{3}$ : Return on asset berpengaruh negatif terhadap praktik income smoothing.

Salah satu dari objek pajak penghasilan adalah Bentuk Usaha Tetap (BUT) (Mardiasmo, 2016). Perusahaan termasuk dalam Bentuk Usaha Tetap, sehingga 
perusahaan juga menjadi objek pajak dan harus menyetorkan pembayaran pajak kepada pemerintah di setiap periode. Dalam teori manajemen laba, salah satu motivasi yang mendorong pihak manajer dalam melakukan income smoothing adalah motivasi pajak. Tindakan income smoothing dapat dilakukan untuk mengurangi pajak penghasilan yang harus dibayarkan perusahaan kepada pemerintah (Arens et al., 2012). Pajak penghasilan yang ditanggung perusahaan akan sangat tergantung dari besar kecilnya laba perusahaan. Semakin besar laba perusahaan maka akan semakin besar pula pajak yang harus ditanggung perusahaan, begitu pula sebaliknya.

Pajak yang tinggi akan menimbulkan beban bagi perusahaan, sehingga akan mendorong manajemen untuk melakukan praktik income smoothing. Hal ini dapat dilakukan dengan memilih metode akuntansi untuk memindahkan laba perusahaan yang tinggi ke tahun berikutnya, sehingga akan mengurangi laba perusahaan. Cara lain yang biasanya digunakan adalah memperbesar tanggungan beban perusahaan, sehingga memperkecil laba dan mengurangi tanggungan pajak penghasilan yang harus dibayarkan oleh perusahaan. Fenomena ini dapat dilihat dari kasus PT Coca Cola Indonesia yang memperbesar biaya iklannya, sehingga menimbulkan penurunan laba dan Penghasilan Kena Pajaknya. Hal ini menyebabkan penurunan pajak penghasilan yang ditanggung perusahaan tersebut. Berdasarkan uraian, maka hipotesis yang diajukan adalah.

$\mathrm{H}_{4}$ : Pajak penghasilan berpengaruh positif terhadap praktik income smoothing.

\section{METODE PENELITIAN}

Penelitian ini menggunakan desain penelitian yang disusun berdasarkan kerangka pemikiran, yaitu pengaruh ukuran perusahaan $\left(X_{1}\right)$, debt to equity ratio $\left(X_{2}\right)$, return on asset $\left(X_{3}\right)$, dan pajak penghasilan $\left(X_{4}\right)$ terhadap yaitu praktik income smoothing (Y). Penelitian ini menggunakan obyek penelitian pada perusahaan manufaktur yang terdaftar di Bursa Efek Indonesia (BEI) dan diakses melalui web www.idx.co.id.

Variabel terikat yang digunakan dalam penelitian ini adalah praktik income smoothing. Income smoothing diukur dengan menggunakan indeks eckel dengan rumus sebagai berikut.

$$
\text { Indeks Eckel }=\frac{\mathrm{cV} \Delta \mathrm{I}}{\mathrm{CV} \Delta \mathrm{S}}
$$

Keterangan:

$\Delta \mathrm{I}=$ Perubahan laba dalam suatu periode.

$\Delta S=$ Perubahan penjualan dalam suatu periode.

$\mathrm{CV}=$ Koefisien variasi untuk perubahan laba dan perubahan penjualan

$\mathrm{CV} \Delta \mathrm{I}$ dihitung sebagai berikut:

$$
\mathrm{CV} \Delta \mathrm{I}=\sqrt{\frac{\sum(\Delta \mathrm{I}-\Delta \mathrm{X})^{2}}{\mathrm{n}-1}}: \Delta \mathrm{X}
$$

Keterangan:

$\Delta \mathrm{I} \quad=$ Perubahan Laba dalam suatu periode.

$\Delta \mathrm{X} \quad=$ Rata-rata perubahan laba bersih setelah pajak antara tahun $\mathrm{n}-1$. 
$\mathrm{n}$

= Banyaknya tahun yang diteliti.

$\mathrm{CV} \Delta \mathrm{S}$ dihitung sebagai berikut:

$$
\mathrm{CV} \Delta \mathrm{S}=\sqrt{\frac{\sum(\Delta \mathrm{S}-\Delta \mathrm{X})^{2}}{\mathrm{n}-1}}: \Delta \mathrm{X}
$$

Apabila indeks income smoothing $<1$ maka perusahaan digolongkan sebagai perusahaan yang melakukan income smoothing dan diberi nilai 1. Jika indeks income smoothing $\geq 1$ maka perusahaan tidak digolongkan sebagai perusahaan yang melakukan income smoothing dan diberi nilai 0 (Gerianta dan Arik, 2011).

Dalam Variabel bebas dalam penelitian ini adalah ukuran perusahaan $\left(\mathrm{X}_{1}\right)$, debt to equity ratio $\left(\mathrm{X}_{2}\right)$, return on asset $\left(\mathrm{X}_{3}\right)$, dan pajak penghasilan $\left(\mathrm{X}_{4}\right)$.

Ukuran perusahaan dihitung dengan skala rasio logaritma natural (Ln) dari total aktiva perusahaan. Rumus yang digunakan untuk mengukur ukuran perusahaan adalah sebagai berikut.

\section{Ukuran Perusahaan $=$ Ln total aktiva}

Debt to equity ratio (DER) merupakan rasio antara utang perusahaan dengan ekuitas perusahaan. Menurut Brigham et al., (2011) semakin tinggi debt to equity ratio perusahaan, maka semakin tinggi pula risiko perusahaan tersebut. Debt to equity ratio dalam penelitian ini menggunakan persentase yang diukur dengan membagi utang perusahaan dengan ekuitas perusahaan yaitu dengan rumus sebagai berikut.

$$
\text { Debt to Equity Ratio }=\frac{\text { Total Utang }}{\text { Total Aktiva }} \times 100 \%
$$

Return on Asset (ROA) adalah rasio persentase laba bersih setelah pajak dengan total aktiva perusahaan (Pratiwi dan Handayani, 2014). Semakin tinggi return on asset suatu perusahaan, maka kinerja perusahaan dinilai semakin baik pula. Return on Asset dihitung dengan rumus sebagai berikut.

$$
\text { Return on Asset }=\frac{\text { Laba Bersih Setelah Pajak }}{\text { Total Aktiva }} \times 100 \% \text {. }
$$

Pajak merupakan kontribusi wajib kepada negara yang terutang oleh orang pribadi/badan yang bersifat memaksa (berdasarkan undang-undang) dengan tidak mendapatkan imbalan secara langsung dan digunakan untuk keperluan negara bagi sebesar-besarnya kemakmuran rakyat (Mardiasmo, 2016). Pajak diukur dengan selisih dari laba sebelum pajak dan laba setelah pajak dengan rumus sebagai berikut.

Pajak = Laba Sebelum Pajak - Laba Setelah Pajak.

\section{HASIL DAN PEMBAHASAN}

Penelitian ini menggunakan statistik deskriptif untuk menyajikan informasi mengenai karekteristik variabel bebas dan terikat perusahaan. statistik deskriptif menyajikan informasi berupa rata-rata (mean), nilai tengah (median), standar deviasi (standard deviation) dan nilai maksimum-minimum. Variabel bebas yang digunakan dalam penelitian ini adalah income smoothing. Sedangkan variabel bebas yang digunakan adalah ukuran perusahaan, debt to equity ratio, return on 
equity, dan pajak penghasilan. Berikut ini disajikan statistik deskriptif untuk masing-masing variabel yang digunakan dalam penelitian ini.

Tabel 1. Analisis Statistik Deskriptif

\begin{tabular}{|c|c|c|c|c|c|}
\hline & Mean & Median & Std. Deviation & Maximum & Minimum \\
\hline Income & 0,260 & 0,176 & 0,700 & 2,409 & $-1,281$ \\
\hline Smoothing & & & & & \\
\hline $\begin{array}{l}\text { Ukuran } \\
\text { Perusahaz }\end{array}$ & in 28,424 & 28,524 & 1,578 & 32,151 & 25,619 \\
\hline $\begin{array}{l}\text { Debt } \\
\text { Equity Rat }\end{array}$ & $\begin{array}{l}\text { to0,854 } \\
\text { io }\end{array}$ & 0,669 & 0,778 & 7,451 & 0,076 \\
\hline Return & on0,092 & 0,075 & 0,096 & 0,946 & 359.007 .284 \\
\hline
\end{tabular}

Asset

$\begin{array}{llllll}\text { Pajak } \quad 235.482 .079 .499 & 38.647 .669 .480 & 497.253 .859 .949 & 2.681 .165 .000 .000 & 6,7016\end{array}$

Penghasilan

Sumber: Data Penelitian, 2019

Berdasarkan Tabel 1, nilai rata-rata untuk variabel $Y$ adalah 0,260 dengan nilai tengah 0, 176. Hal ini berarti rata-rata perusahaan manufaktur di Bursa Efek Indonesia tidak melakukan praktik income smoothing pada periode 2013-2017, karena memiliki indeks eckel yang kurang dari 1. Nilai maksimum untuk variabel Y adalah 2,409 pada perusahaan PT Champion Pasific Indonesia Tbk, dan nilai minimum sebesar -1,281 pada perusahaan PT Arwana Citramulia Tbk. Standar Deviasi untuk income smoothing adalah 0,700.

Berdasarkan Tabel 1, nilai maksimum untuk variabel $\mathrm{X}_{1}$ adalah 32,151 pada perusahaan Indofood Sukses Makmur Tbk. Nilai minimum untuk variabel $X_{1}$ adalah 25,619 pada perusahaan Lionmesh Prima Tbk. Hal ini menunjukkan ukuran perusahaan manufaktur di Bursa Efek Indonesia pada periode 2013-2017 adalah antara 25,619 dan 32,151. Median variabel $X_{1}$ adalah 28,524. Rata-rata ukuran perusahaan manufaktur adalah 28,424 dengan standar deviasi sebesar 1,578 .

Berdasarkan Tabel 1, variabel $\mathrm{X}_{2}$ (debt to equity ratio) memiliki nilai minimum sebesar 0,076 pada perusahaan Intan Wijaya International Tbk dan memiliki nilai maksimum 7,451 pada perusahaan Jembo Cable Company. Hal ini menunjukkan perusahaan manufaktur yang terdaftar di Bursa Efek Indonesia memiliki debt to equity ratio tertinggi sebesar 7,451 dan terendah sebesar 0,076. Rata-rata debt to equity ratio pada perusahaan manufaktur di Bursa Efek Indonesia adalah 0,854 dengan standar deviasi 0,778.

Berdasarkan Tabel 1, variabel $\mathrm{X}_{3}$ (Return on asset) memiliki nilai minimum sebesar 0,001 pada perusahaan Nusantara Inti Tbk, dan memiliki nilai maksimum sebesar 0,946 pada perusahaan Siantar Top Tbk. Hal ini menunjukkan return on asset perusahaan manufaktur di Bursa Efek Indonesia periode 2013-2017 adalah antara 0,001 dan 0,946. Rata-rata profitbilitas perusahaan manufaktur periode 2013-2017 adalah 0,092 dengan standar deviasi sebesar 0,096.

Berdasarkan Tabel 1, variabel $\mathrm{X}_{4}$ (Pajak Penghasilan) memiliki nilai minimum sebesar 359.007.284 dan nilai maksimum sebesar 2.681.165.000.000. Hal ini menunjukkan bahwa perusahaan manufaktur yang terdaftar di Bursa Efek Indonesia periode 2013-2017 menanggung beban pajak penghasilan antara Rp 359.007.284 dan $\operatorname{Rp}$ 2.681.165.000.000. Rata-rata perusahaan manufaktur 
membayar pajak sebesar Rp 235.482.079.499 dengan standar deviasi $\mathrm{Rp}$ 497.253.859.949.

- Pengujian normalitas data penelitian ini menggunakan metode Kolmogorov-Smirnov. Data penelitian dikatakan berdistribusi normal apabila nilai Asymp. Sig (2-tailed) lebih besar daripada tingkat signifikansi sebesar 5\% atau 0,05. Berikut hasil uji normalitas penelitian dapat dilihat pada Tabel 2, sebagai berikut.

Tabel 2. Uji Normalitas

\begin{tabular}{lll}
\hline & & $\begin{array}{l}\text { Unstandardized } \\
\text { Residual }\end{array}$ \\
\hline $\mathrm{N}$ & & 264 \\
Normal Parametersa,b & Mean & -.0063658 \\
& Std. Deviation & .44778514 \\
Most Extreme Differences & Absolute & .083 \\
& Positive & .067 \\
Kolmogorov-Smirnov Z & Negative & -.083 \\
Asymp. Sig. (2-tailed) & & 1.356 \\
\hline
\end{tabular}

Sumber: Data Penelitian, 2019

Berdasarkan Tabel 2, nilai Asymp. Sig (2-tailed) adalah sebesar 1,356 yang lebih besar daripada 0,05. Hal ini berarti bahwa seluruh data pada model persamaan regresi dengan variabel dependen Praktik Income Smoothing sudah berdistribusi secara normal.

Uji heteroskedastisitas digunakan untuk menguji apakah dalam sebuah model regresi berganda terjadi ketidaksamaan varians dari residual satu pengamatan ke pangamatan yang lain. Cara untuk mendeteksi adanya heterokedastisitas adalah dengan melakukan uji glejser, yaitu meregresikan nilai absolut $e_{i}$ variabel terikat dengan variabel bebas. Suatu model regresi akan dikatakan bebas dari heterokedastisitas apabila nilai signifikansi tiap variabel bebas diatas tingkat signifikansi 0,05 . Hasil uji hesteroskedastisitas penelitian terdapat pada Tabel 3.

Tabel 3. Uji Heterokedastisitas

\begin{tabular}{lll}
\hline \multicolumn{1}{c}{ Variabel } & Sig. & Keterangan \\
\hline Ukuran perusahaan $\left(\mathrm{X}_{1}\right)$ & 0,846 & Bebas heteroskedasitas \\
Debt to Equity Ratio $\left(\mathrm{X}_{2}\right)$ & 0,621 & Bebas heteroskedasitas \\
Return on Asset $\left(\mathrm{X}_{3}\right)$ & 0,556 & Bebas heteroskedasitas \\
Pajak penghasilan $\left(\mathrm{X}_{4}\right)$ & 0,596 & Bebas heteroskedasitas \\
\hline
\end{tabular}

Sumber: Data Penelitian, 2019

Berdasarkan Tabel 3, menunjukkan bahwa nilai signifikansi untuk variabel ukuran perusahaan $\left(X_{1}\right)$ sebesar 0,846 , untuk variabel debt to equity ratio $\left(X_{2}\right)$ sebesar 0,621 , untuk variabel return on asset $\left(X_{3}\right)$ sebesar 0,556 dan untuk variabel pajak penghasilan $\left(X_{4}\right)$ sebesar 0,596 , masing-masing nilai tersebut lebih besar dari 0,05. Hal ini menunjukkan bahwa model regresi bebas dari gejala heteroskedastisitas.

Suatu model regresi jika mengandung gejala autokorelasi, maka prediksi yang dilakukan dengan model tersebut akan tidak baik, atau dapat memberikan hasil prediksi yang menyimpang. Uji autokorelasi dilakukan untuk melacak adanya korelasi data dari tahun $t$ dengan tahun $t-1$ (sebelumnya). Pengujian 
autokorelasi dilakukan melalui Durbin-Watson test, dimana model regresi dikatakan terbebas dari autokorelasi apabila sesuai dengan kriteria $\mathrm{du}<\mathrm{DW}<4$ du. Hasil uji autokorelasi dapat dilihat pada Tabel 4.

\section{Tabel 4. Uji Autokorelasi}

\begin{tabular}{llllll}
\hline No & Dl & Du & 4-du & DW & Simpulan \\
\hline 1 & 1,75763 & 1,81045 & 2,1895 & 2,118 & Bebas autokorelasi \\
\hline \multicolumn{2}{l}{ Sumber: } & Data Penelitian, 2019 & & &
\end{tabular}

Tabel 4, menunjukkan bahwa besarnya nilai Durbin Watson sebesar 1,995.

Nilai D-W menurut tabel dengan $\mathrm{n}=235$ dan $\mathrm{k}=4$ didapat nilai dl=1,675 dan nilai $\mathrm{du}=1,810$. Oleh karena nilai $\mathrm{du}<\mathrm{dw}<(4-\mathrm{du})$ yaitu $(1,810<2,118<2,189)$, maka dapat disimpulkan tidak terdapat autokorelasi antar residual.

Uji multikolinieritas adalah pengujian yang bertujuan untuk menguji apakah dalam model regresi ditemukan adanya kolerasi antarvariabel independen. Untuk mendeteksi ada atau tidaknya multikolinieritas di dalam model regresi dalam penelitian ini dengan melihat tolerance, dan variance inflation factor (VIF). Hasil nilai tolerance yang nilainya lebih besar dari 10 persen $(0,10)$ dan VIF yang besarnya kurang dari 10 mengindikasikan tidak adanya gejala multikolinieritas (Ghozali, 2011: 105). Hasil uji multikolinieritas penelitian dapat dilihat pada Tabel 5.

Tabel 5. Uji Multikolinieritas

\begin{tabular}{lcc}
\hline Variabel & Tolerance & VIF \\
\hline Ukuran perusahaan $\left(\mathrm{X}_{1}\right)$ & 0,486 & 2,059 \\
Debt to Equity Ratio $\left(\mathrm{X}_{2}\right)$ & 0,958 & 1,044 \\
Return on Asset $\left(\mathrm{X}_{3}\right)$ & 0,956 & 1,046 \\
Pajak penghasilan $\left(\mathrm{X}_{4}\right)$ & 0,480 & 2,081 \\
\hline
\end{tabular}

Sumber: Data Penelitian, 2019

Berdasarkan Tabel 5, dapat dilihat bahwa nilai tolerance pada masingmasing variabel lebih besar dari $10 \%(0,1)$, demikian pula dengan nilai VIF masing-masing variabel yang lebih kecil dari 10 . Hal ini menandakan bahwa pada persamaan regresi linier berganda dengan variabel dependen praktik income smoothing ini tidak terdapat korelasi antar variabel bebas sehingga persamaan ini bebas dari gejala multikolinearitas.

Tabel 6. Hasil Uji Regresi Linier Berganda

\begin{tabular}{|c|c|c|c|c|c|}
\hline \multirow[t]{2}{*}{ Model } & \multicolumn{2}{|c|}{$\begin{array}{l}\text { Unstandardized } \\
\text { Coefficients }\end{array}$} & \multirow{2}{*}{$\begin{array}{l}\text { Standardized } \\
\text { Coefficients } \\
\text { Beta }\end{array}$} & \multirow[t]{2}{*}{$\mathrm{T}$} & \multirow[t]{2}{*}{ Sig. } \\
\hline & B & Std. Error & & & \\
\hline (Constant) & 5,276 & 1,093 & & 4,828 & 0,000 \\
\hline Ukuran Perusahaan & $-0,185$ & 0,039 & $-0,421$ & $-4,717$ & 0,000 \\
\hline Debt to Equity Ratio & 0,030 & 0,057 & 0,033 & 0,524 & 0,601 \\
\hline Return on Asset & 1,105 & 0,458 & 0,153 & 2,414 & 0,017 \\
\hline Pajak Penghasilan & 0,001 & 0,000 & 0,360 & 4,014 & 0,000 \\
\hline
\end{tabular}

Sumber: Data Penelitian, 2019

Berdasarkan Tabel 6, model persamaan regresi adalah sebagai berikut.

$$
\mathrm{Y}=5,276-0,185 \mathrm{X} 1+0,030 \mathrm{X} 2+1,105 \mathrm{X} 3+0,001 \mathrm{X} 4
$$

Nilai konstanta adalah 5,276, menunjukkan bahwa jika semua variabel bebas bernilai nol, maka nilai dari indeks eckel adalah 5,276. 
Nilai koefisien untuk variabel $\mathrm{X}_{1}$ (ukuran perusahaan) adalah sebesar 0,185 . Hal ini berarti setiap peningkatan ukuran perusahaan sebesar $1 \%$, maka indeks eckel akan menurun sebesar 0,185\%.

Nilai koefisien regresi untuk variabel $\mathrm{X}_{2}$ (debt to equity ratio) adalah sebesar 0,030 . Hal ini berarti setiap peningkatan debt to equity ratio sebesar $1 \%$, maka indeks eckel akan meningkat sebesar 0,030\%.

Nilai koefisien regresi untuk variabel $X_{3}$ (return on asset) adalah sebesar 1,105 . Hal ini berarti setiap peningkatan return on asset sebesar $1 \%$, maka indeks eckel akan meningkat sebesar 1,105\%.

Nilai koefisien regresi untuk variabel $\mathrm{X}_{4}$ (pajak penghasilan) adalah sebesar 0,001 . Hal ini berarti setiap peningkatan pajak penghasilan sebesar $1 \%$, maka indeks eckel akan meningkat sebesar $0.001 \%$.

Kemampuan model dalam menerangkan variasi variabel independen dapat diukur dengan menggunakan uji koefisen determinasi. Nilai koefisien determinisi dapat dilihat pada adjusted $\mathrm{R}^{2}$ dalam model regresi. Peneliti menggunakan nilai adjusted $\mathrm{R}^{2}$ pada saat mengevaluasi yang mana model regresi terbaik, karena nilai adjusted $\mathrm{R}^{2}$ dapat naik atau turun apabila satu variabel independen ditambahkan ke dalam model. Hasil uji koefisien determinasi dapat dilihat pada Tabel 7, berikut.

Tabel 7. Uji Koefisien Determinasi

\begin{tabular}{lllll}
\hline Model & $\mathrm{R}$ & $\mathrm{R}$ Square & Adjusted R Square & $\begin{array}{l}\text { Std. Error of the } \\
\text { Estimate }\end{array}$ \\
\hline 1 & $0,334^{\mathrm{a}}$ & 0,112 & 0,096 & 0,66015 \\
\hline
\end{tabular}

Sumber: Data Penelitian, 2019

Berdasarkan hasil uji koefisien determinasi pada Tabel 3, diperoleh besarnya adjusted $\mathrm{R}^{2}$ (koefisien determinasi yang telah disesuaikan) adalah 0,096. Ini berarti variasi praktik income smoothing dapat dipengaruhi secara signifikan oleh variabel ukuran perusahaan, debt to equity ratio, return on asset, dan pajak penghasilan sebesar 9,6 persen sedangkan sisanya sebesar 90,4 persen dijelaskan oleh faktor-faktor lain yang tidak dijelaskan dalam model penelitian.

Penelitian ini menggunakan uji kelayakan model. Uji kelayakan model regresi bertujuan untuk mengetahui apakah semua variabel bebas yang diidentifikasi (ukuran perusahaan, debt to equity ratio, return on asset, dan pajak penghasilan) tepat digunakan memprediksi variabel terikat (praktik income smoothing). Uji ini sering juga disebut dengan uji F. Hasil uji F dapat dilihat pada Tabel 8, berikut.

Tabel 8. Uji Statistik F

\begin{tabular}{|c|c|c|c|c|c|}
\hline Model & Sum of Squares & Df & Mean Square & $\mathrm{F}$ & Sig. \\
\hline Regression & 12,589 & 4 & 3,147 & 7,222 & $0,000^{\mathrm{b}}$ \\
\hline Residual & 100,235 & 230 & 0,436 & & \\
\hline Total & 112,824 & & & & \\
\hline
\end{tabular}

Sumber: Data Penelitian, 2019

Hasil uji kelayakan model (Uji F) pada Tabel 4, menunjukkan bahwa nilai F hitung sebesar 7,222 dengan nilai signifikansi $\mathrm{P}$ value 0,000 yang lebih kecil dari a $=0,05$, ini berarti model yang digunakan pada penelitian ini adalah layak. Hasil ini memberikan makna bahwa seluruh variabel independen yaitu ukuran 
perusahaan, debt to equity ratio, return on asset, dan pajak penghasilan tepat memprediksi atau menjelaskan fenomena praktik income smoothing di perusahaan manufaktur di Bursa Efek Indonesia periode 2013-2017. Dengan kata lain, ukuran perusahaan, debt to equity ratio, return on asset, dan pajak penghasilan secara simultan berpengaruh signifikan pada praktik income smoothing.

Untuk menilai Keseluruhan Model (Overal Model Fit) pada analisis regresi logistik dapat dilakukan dengan Uji Binary Logistik. Pengujian ini dilakukan dengan cara menilai angka -2 log likelihood. Apabila terjadi penurunan angka -2 $\log$ likelihood dari awal (blok number $=0$ ) pada angka -2 log likelihood pada blok number $=1$, maka menunjukkan model regresi yang baik. Uji Binary Logistik dapat dilihat pada Tabel 9, berikut.

Tabel 9. Uji Binary Logistik

\section{$2 \log$ likelihood \\ blok number $=0$}

blok number $=1$

\begin{tabular}{llllll}
\hline Step & 1 & 184.942 & Step 1 & 1 & 136.705 \\
0 & 2 & 179.586 & & 2 & 105.355 \\
& 3 & 179.499 & 3 & 97.838 \\
& 4 & 179.499 & & 4 & 96.807 \\
& 5 & 179.499 & & 5 & 96.771 \\
& & & 6 & 96.771 \\
& & & & 7 & 96.771
\end{tabular}

Sumber: Data Penelitian, 2019

Hasil uji Keseluruhan Model (Overal Model Fit) pada Tabel diatas menunjukkan bahwa angka $-2 \log$ likelihood pada awal (blok number $=0$ ) dan -2 $\log$ likelihood pada blok number $=1$ mengalami penurunan, hal ini menunjukkan model regresi yang baik.

Dasar pengambilan keputusan menggunakan nilai godness of fit test yang diukur dengan nilai chis square pada bagian bawah uji Hosmer dan Lemeshow. Apabila probabilitas $>0,05$ maka Ho diterima dan Ha ditolak, sebaliknya apabila probabilitas < 0,05 maka Ho ditolak dan Ha diterima. Hasil uji Hosmer dan Lemeshow dapat dilihat pada Tabel 6.

Tabel 10. Uji Hosmer dan Lemeshow

\begin{tabular}{cccc}
\hline Step & Chi-Square & Df & Sig \\
\hline 1 & $0,334^{\text {a }}$ & 0,112 & 0,096
\end{tabular}

Sumber: Data Penelitian, 2019

Nilai Chi Square tabel untuk DF 8 pada taraf signifikansi 0,05 adalah sebesar 14,067. Karena nilai Chi Square Hosmer and Lemeshow hitung 199,092 > Chi Square table 14,067 atau nilai signifikansi sebesar 0,000 lebih kecil dari 0,05, sehingga menerima $\mathrm{Ha}$, yang menunjukkan bahwa model dapat diterima dan pengujian hipotesis dapat dilakukan sebab ada perbedaan yang signifikan antara model dengan nilai observasinya.

Besarnya nilai koefisien determinasi pada regresi logistik ditunjukkan dengan nilai Nagelkerke $R$ Square. Hasil uji Nagelkerke $R$ Square dalam penelitian ini dapat dilihat pada Tabel 7 . 
Tabel 11. Uji Nagelkerke R Square

\begin{tabular}{llll}
\hline Step & -2Log likehood & Cox E Snell R Square & Nagelkerke R Square \\
\hline 1 & $96.771^{\mathrm{a}}$ & 0,297 & 0,556 \\
\hline
\end{tabular}

Sumber: Data Penelitian, 2019

Hasil uji pada Tabel 11, memberikan hasil dimana diperoleh nilai Nagelkerke $R$ Square adalah sebesar 0,556. Ini berarti variasi praktik income smoothing di perusahaan manufaktur di Bursa Efek Indonesia periode 2013-2017 dapat dipengaruhi secara signifikan oleh variabel ukuran perusahaan, debt to equity ratio, return on asset, dan pajak penghasilan sebesar 55,6 persen, sedangkan sisanya sebesar 44,4 persen dijelaskan oleh faktor-faktor lain yang tidak dijelaskan dalam model penelitian.

Berdasarkan hasil analisis pengaruh Ukuran perusahaan terhadap Praktik Income Smoothing pada Tabel 6, diperoleh nilai signifikansi sebesar 0,000 dengan nilai koefisien regresi negatif sebesar $-0,185$. Nilai signifikansi $0,000<$ 0,050 mengindikasikan bahwa $\mathrm{H}_{1}$ diterima. Dapat disimpulkan bahwa ukuran perusahaan berpengaruh negatif dan signifikan terhadap praktik income smoothing.

Hasil penelitian ini sejalan dengan penelitian yang dilakukan oleh Akbar Kharisma \& Linda Agustina, (2015) yang mendapatkan hasil bahwa ukuran perusahaan berpengaruh negatif signifikan terhadap praktik income smoothing. Oleh karena itu, perusahaan yang berukuran kecil akan lebih cenderung untuk melakukan praktik income smoothing dibandingkan dengan perusahaan yang berukuran besar. Hal ini dikarenakan perusahaan yang berukuran besar akan lebih menarik perhatian masyarakat, investor, dan pemerintah, sehingga perusahaan akan mempersempit peluang manajemen perusahaan untuk melakukan praktik income smoothing.

Hasil penelitian ini tidak sejalan dengan penelitian yang dilakukan oleh Prasetya, (2013) yang menemukan bahwa ukuran perusahaan tidak memiliki pengaruh terhadap praktik income smoothing.

Berdasarkan hasil analisis pengaruh debt to equity ratio terhadap praktik income smoothing diperoleh nilai signifikansi sebesar 0,601 dengan nilai koefisien regresi positif sebesar 0,030. Nilai signifikansi 0,601 >0,050 mengindikasikan bahwa $\mathrm{H}_{2}$ ditolak. Hasil ini mempunyai arti bahwa debt to equity ratio tidak berpengaruh signifikan terhadap praktik income smoothing.

Hasil penelitian ini mendukung penelitian yang dilakukan oleh Olivya Pramono (2013) dan Ida Ayu Ratih Manuari (2014) yang menemukan bahwa debt to equity ratio tidak memiliki pengaruh terhadap praktik income smoothing. Oleh karena itu, dapat disimpulkan bahwa perubahan rasio debt to equity ratio suatu perusahaan tidak berdampak terhadap praktik income smoothing. Hasil tersebut berbeda dari hasil penelitian yang dilakukan oleh Ayu \& Damayanti, (2015) yang menemukan bahwa debt to equity ratio berpengaruh signifikan terhadap praktik income smoothing.

Berdasarkan hasil analisis pengaruh Return on Asset terhadap Praktik Income Smoothing pada Tabel 6, diperoleh nilai signifikansi sebesar 0,017 dengan nilai koefisien regresi positif sebesar 1,105. Nilai signifikansi 0,017 < 0,050 mengindikasikan bahwa $\mathrm{H}_{3}$ diterima. Sehingga dapat disimpulkan bahwa return 
on asset berpengaruh negatif dan signifikan terhadap praktik income smoothing. Oleh karena itu, semakin tinggi return on asset suatu perusahaan, maka semakin kecil kemungkinan perusahaan tersebut untuk melakukan praktik income smoothing.

Penelitian ini menunjukkan bahwa return on asset merupakan salah satu faktor yang mendorong manajemen perusahaan untuk melakukan praktik income smoothing. Rasio return on asset telah menarik perhatian investor untuk pengambilan keputusan dalam kegiatan investasi. Hasil ini mendukung penelitian dari Herlinda Pratiwi dan Bestari Dwi Handayani (2014) yang menemukan bahwa profitabilitas berpengaruh negatif signifikan terhadap praktik income smoothing. Perusahaan yang memiliki rasio return on asset rendah cenderung akan melakukan praktik income smoothing, karena perusahaan akan tertekan untuk pembayaran utang atau kewajibannya.

Hasil penelitian ini tidak sejalan dengan penelitian yang dilakukan oleh Olivya Pramono (2013) yang menemukan bahwa return on asset perusahaan tidak memiliki pengaruh terhadap praktik income smoothing.

Berdasarkan hasil analisis pengaruh Pajak penghasilan terhadap Praktik Income Smoothing pada Tabel 6, diperoleh nilai signifikansi sebesar 0,000 dengan nilai koefisien regresi positif sebesar 0,001. Nilai signifikansi 0,000<0,050 mengindikasikan bahwa $\mathrm{H}_{4}$ diterima. Hasil ini mempunyai arti bahwa Pajak penghasilan berpengaruh positif dan signifikan terhadap Praktik Income Smoothing. Semakin tinggi laba suatu perusahaan, maka semakin tinggi pula pajak yang harus dibayar oleh perusahaan, sehingga akan mendorong manajemen untuk melakukan praktik income smoothing.

Hasil tersebut berbeda dari hasil penelitian yang dilakukan oleh Pratiwi \& Handayani (2014) yaitu pajak tidak memiliki pengaruh yang signifikan terhadap praktik income smoothing. Hal ini menandakan bahwa dengan pajak yang rendah atau tinggi, manajemen tetap melakukan praktik income smoothing untuk memenuhi kebutuhan ekonomis dan psikologisnya.

\section{SIMPULAN}

Berdasarkan hasil pengujian analisis data dan pembahasan yang telah dilakukan pada bab sebelumnya, maka dapat ditarik simpulan berdasarkan hasil penelitian. Ukuran perusahaan berpengaruh negatif signifikan terhadap income smoothing. Hal ini berarti semakin besar ukuran perusahaan, maka perusahaan tidak cenderung untuk melakukan income smoothing. Debt to Equity Ratio tidak berpengaruh signifikan terhadap income smoothing. Hal ini berarti, semakin besar debt to equity ratio perusahaan maka perusahaan tidak akan cenderung melakukan income smoothing. Return on Asset dan pajak penghasilan berpengaruh positif dan signifikan terhadap income smoothing. Hal ini berarti semakin rendah return on asset atau pajak penghasilan perusahaan, maka perusahaan cenderung untuk melakukan income smoothing.

Berdasarkan hasil dari penelitian yang telah dilakukan, maka terdapat beberapa saran yang dapat diajukan diantaranya adalah peneliti selanjutnya diharapkan untuk tidak hanya menggunakan perusahaan manufaktur yang terdaftar di Bursa Efek Indonesia, akan tetapi juga dapat menggunakan jenisjenis perusahaan lain agar hasil penelitian lebih representatif dan peneliti 
selanjutnya diharapkan untuk menambah kurun waktu penelitian. Penambahan kurun waktu bertujuan agar dapat melihat perbedaan hasil dengan penelitian sebelumnya.

\section{REFERENSI}

Akbar Kharisma \& Linda Agustina. (2015). Pengaruh Mekanisme Corporate Governance Dan Ukuran Perusahaan Terhadap Praktik Perataan Laba. Accounting Analysis Journal. https:// doi.org/10.15294/aaj.v4i2.7857

Amanza, A. H., \& Rahardjo, S. N. (2012). Analisis Faktor-Faktor Yang Mempengaruhi Praktik Perataan Laba ( Income Smoothing ). Diponegoro Journal of Accounting, 1(1), 2-13.

Arens, A. A., Elder, J. R., \& Beasley, S. M. (2012). Auditing and Assurance Services: An Integrated Approach 14th Edition. In Orbit An International Journal On Orbital Disorders And Facial Reconstructive Surgery. https:// doi.org/10.1016/0005-1098(86)90018-X.

Armein, R. A. (2005). Analisis Kasus Laporan Keuangan PT Indofarma Tbk. Jurnal Universitas Pelita Harapan Vol. IV No. 13.

Atik, A. (2009). Detecting income-smoothing behaviors of Turkish listed companies through empirical tests using discretionary accounting changes. Critical Perspectives on Accounting. https:/ / doi.org/10.1016/j.cpa.2008.01.003

Ayu, I. G., \& Damayanti, E. (2015). Pengaruh Ukuran Perusahaan , Debt To Equity Ratio, Profitabilitas Dan Kepemilikan. 1, 208-223.

Brigham, F, E., \& Houston. (2011). Dasar-dasar Manajemen Keuangan Terjemahan. Edisi 10. Jakarta: Selemba Empat.

Ghozali, I. (2011). Aplikasi Analisis Multivariate Dengan Program IBM SPSS 19 (edisi kelima). In Aplikasi Analisis Multivariate dengan program SPSS. https:// doi.org/10.9744/jmk.10.2.pp. 124-135

Idawati, W., \& Wahyudi, A. (2015). Effect of Earning Per Share (EPS) and Return On Assets (ROA) Against Share Price on Coal Mining Company Listed in Indonesia Stocks Exchange. Journal of Resource Development and Management.

Jariah, A. (2016). Tindakan Perataan Laba Pada Perusahaan Jasa Di Indonesia Dengan Ukuran Perusahaan, Rasio Profitabilitas, Dan Leverage Sebagai Variabel Pembeda. Jurnal Penelitian Ilmu Ekonomi Wiga.

Josep, W., AR, M., \& Azizah, D. (2016). Pengaruh Ukuran Perusahaan, Return On Asset Dan Net Profit Margin Terhadap Perataan Laba (Income Smoothing) (Studi pada Perusahaan Manufaktur yang Terdaftar di BEI 2012-2014). Jurnal Administrasi Bisnis S1 Universitas Brawijaya.

Koh, P. S. (2003). On the association between institutional ownership and aggressive corporate earnings management in Australia. British Accounting Review. https://doi.org/10.1016/S0890-8389(03)00014-3

Lestari, Y. R. D. (2017). Pengaruh Profitabilitas, Financial Leverage, dan Ukurun Perusahaan terhadap Perataan Laba pada Perusahaan Manufaktur Sub Sektor Makanan dan Minuman yang Terdaftar di Bursa Efek Indonesia Periode 2011-2014. Artikel Skripsi. Fakultas Ekonomi Universitas Nusantara PGRI Kediri.

Manuari, I. A. R., \& Yasa, G. W. (2014). Praktik Perataan Laba dan Faktor - Faktor yang Mempengaruhinya. E-Jurnal Akuntansi Universitas Udayana. 
Mardiasmo. (2016). Perpajakan Edisi Revisi 2016. In Journal of Chemical Information and Modeling. https:/ / doi.org/10.1017/CBO9781107415324.004

Prasetya, H. (2013). Pengaruh Ukuran Perusahaan, Profitabilitas, Financial Leverage, Klasifikasi Kap Dan Likuiditas Terhadap Praktik Perataan Laba. Diponegoro Journal of Accounting.

Pramono, O. (2013). Analisis Pengaruh ROA, NPM, DER, dan Size Terhadap Praktik Perataan Laba (Studi Kasus pada Perusahaan Manufaktur yang Terdaftar di Bursa Efek Indonesia Periode 2007-2011). Jurnal Ilmiah Mahasiswa. Universitas Surabaya. Vol. 2. No.2

Pratiwi. H. dan Handayani B.D. (2014). Pengaruh Profitabilitas, Kepemilikan Manajerial dan Pajak terhadap Praktik Perataan Laba. Jurnal Akuntansi Universitas Semarang.

Rydqvist, K., Schwartz, S. T., \& Spizman, J. D. (2014). The tax benefit of income smoothing. Journal of Banking and Finance, 38, 78-88. https:// doi.org/10.1016/j.jbankfin.2013.09.017 